\title{
Performance of Bambara groundnut (Vigna subterranea L. Verdc.) with rice husk biochar and Christmas Island Rock Phosphate application
}

\author{
Mukhtar Musa ${ }^{1,2,3}$ (D) Ajit Singh ${ }^{1}(\mathbb{0})$
}

Received: 30 April 2018 / Accepted: 9 June 2019 / Published online: 14 June 2019

(c) The Author(s) 2019

\begin{abstract}
Purpose Biochar application could be a sustainable way to enhance the nitrogen fixation in Bambara groundnut and other legumes. The research was conducted to study the effect of rice husk biochar and the Christmas Island Rock Phosphate application on the performance of Bambara groundnut in the study area.

Methods Two levels of rice husk biochar (0 and 10 t/ha) and four levels of Christmas Island Rock Phosphate (0, 20, 40 and $60 \mathrm{~kg} \mathrm{P} \mathrm{O}_{5} / \mathrm{ha}$ ) were factorially combined to make a total of eight treatment combinations which were laid out in a randomized complete block design (RCBD) with three replicates. Data were collected on nitrogen content and fixation of the crop.

Results Application of rice husk biochar increased the total mean of nitrogen content and $\mathrm{N}$ fixed by the crop from 120.0 and $90.9 \mathrm{~kg} / \mathrm{ha}$ to 147.6 and $114.1 \mathrm{~kg} / \mathrm{ha}$, respectively. However, the effect of rock phosphate application on the nitrogen content and fixation of the crop was not observed.

Conclusion Rice husk biochar application at $10 \mathrm{t} / \mathrm{ha}$ alone was sufficient for nitrogen content and fixation of the crop. This implies that farmers in the study area can apply rice husk biochar at $10 \mathrm{t} / \mathrm{ha}$ to enhance the performance of the crop.
\end{abstract}

Keywords Biochar $\cdot$ Grain legumes $\cdot$ Rock phosphate $\cdot$ Subhumid tropics

\section{Introduction}

Bambara groundnut (Vigna subterranea (L.) Verdc.) is an African legume grown for its grains, which can be prepared and consumed in different forms and diets (Collinson et al. 1996). The crop is next to cowpea (Vigna unguiculata L. Walp.) and peanut (Arachis hypogaea L.) among the most important legumes grown in the region (Howell et al. 1994). The seeds of the crop contain 16-25\% protein, 5-6\% lipid, 42-60\% carbohydrate, $4.8 \%$ fibre, and 3.4\% ash (Brough and Azam-Ali 1992). The crop fixes 20-100 kg N/ha (Musa et al. 2016). Bambara groundnut such as other grain legumes

Ajit Singh

Ajit.singh@nottingham.edu.my

1 School of Biosciences, University of Nottingham, Malaysia Campus, 43500 Semenyih, Selangor, Malaysia

2 Crops for the Future, University of Nottingham, Malaysia Campus, 43500 Semenyih, Selangor, Malaysia

3 Department of Crop Science, Usmanu Danfodiyo University, P.M.B. 2346, Sokoto, Sokoto State, Nigeria is an important component of African traditional cropping systems grown as intercrop or in rotation with other crops such as sorghum (Sorghum vulgare) and pearl millet (Pennisetum glaucum) (Dakora and Keya 1997).

Biochar is a product of thermal decomposition of biomass under oxygen-limited conditions (pyrolysis). It is a solid material that is rich in organic materials and is gaining popularity by both researchers and farmers because of its potential benefits in increasing crop yield (Chen et al. 2011; Dong et al. 2016). Biochar enhances the availability of basic nutrients ( $\mathrm{Ca}$ and $\mathrm{Mg}$ ) in acid soils, soil moisture retention, $\mathrm{N}$ retention, and use efficiency, thus increasing crop productivity (Liu et al. 2013). Biochar inhibits the mineralization of organic $\mathrm{N}$ to ammonia or nitrate and adsorbs ammonium or nitrate which renders it less available for leaching (Jin et al. 2016). It increases nutrient use efficiency by retaining soil-applied nutrients in the topsoil within the root zone of most crops (Lehmann et al. 2003; Barrow 2012). Biochar increases the moisture retention capacity of soils via increased soil aggregation and decreased bulk density (Dong et al. 2016). 
Bambara groundnut such as other legumes has a high $\mathrm{P}$ requirement (20-60 $\mathrm{kg} \mathrm{P}_{2} \mathrm{O}_{5} / \mathrm{ha}$ ) which is essential due to higher ATP requirements for nitrogenase activity, nodule development, and function (Graham and Vance 2000) and its deficiency limits the performance of the crop (LópezBucio et al. 2002). The high cost of conventional P fertilizers could constrain the production of the crop (Fardeau and Zapata 2002). Hence, evaluation of the response of the crop to locally and easily available sources of $P$ such as rock phosphate could help to address the constraint and increase the yield of the crop. Rock phosphate application reduces the cost of fertilizer application and mitigates adverse environmental effects (Arcand and Schneider 2006). Research on cowpea by Sokoto and Singh (2008) reported rock phosphate application at $25 \mathrm{~kg} / \mathrm{ha}$ to increase the yield and its components in cowpea.

To date, information on the influence of biochar and rock phosphate application on nitrogen fixation in Bambara groundnut is limited, but in common bean (Phaseolus vulgaris L.), biochar application was reported to increase the $\mathrm{N}$ fixation of the crop which was attributed to the increase in K, Ca, P, B, and Mo availability (Rondon et al. 2007). In addition, Hossain et al. (2010) working on acid soils ( $\mathrm{pH}$ 4.6) in Camden, the south-western region of Sydney, Australia reported an application of $10 \mathrm{t} / \mathrm{ha}$ biochar from wastewater sludge to maximize the yield of cherry tomato. Similarly, Biochar application increases the production of maize (Major et al. 2010), peanut (Yamato et al. 2006), common bean (Raboin et al. 2016), and rice (Steiner et al. 2007).

Thus, the research was conducted to study the effect of biochar and rock phosphate application on the performance of Bambara groundnut in the study area.

\section{Methodology}

\section{Site}

The research was conducted at the Crops for the Future (CFF) Research Farm, Semenyih, Selangor Malaysia (Latitude 2.931083, Longitude 101.878323 at $42 \mathrm{~m}$ above sea level). The soil at the site is Ultisols (Rengam soil series, a clayey, kaolinitic, isohyperthermic Typic Paleudult) (Fardeau and Zapata 2002; Radin et al. 2018). The investigation was conducted from February to June 2015 (first trial) and repeated from August to December 2015 (second trial). The total rain received was 853.6 and $1225 \mathrm{~mm}$, for the first and second trial, respectively (Figs. 1 and 2). The mean maximum and minimum temperatures for the first and second trials were 33.5 and $22.8^{\circ} \mathrm{C}$, and 33.0 and $22.8^{\circ} \mathrm{C}$, respectively. The mean maximum and minimum relative humidity recorded during the first and second trials were 97.0 and $50.5 \%$ and 98.5 and $54.1 \%$, respectively. The mean

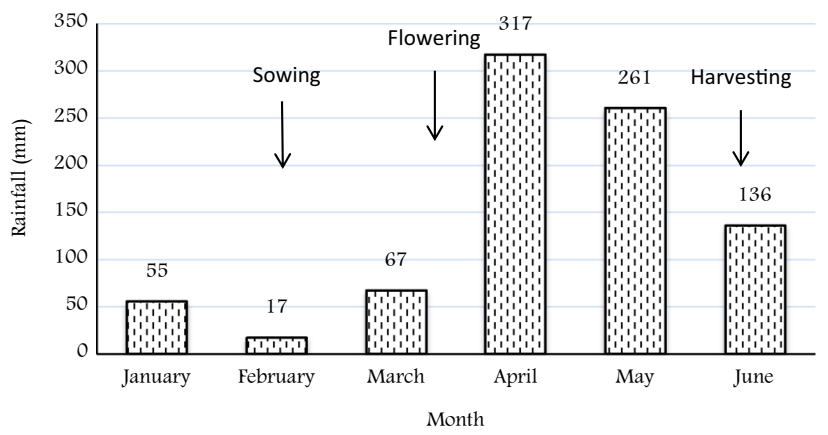

Fig. 1 Sowing and harvesting time and the monthly rainfall at the research site from January to June 2015 . Total rainfall $=853.6 \mathrm{~mm}$

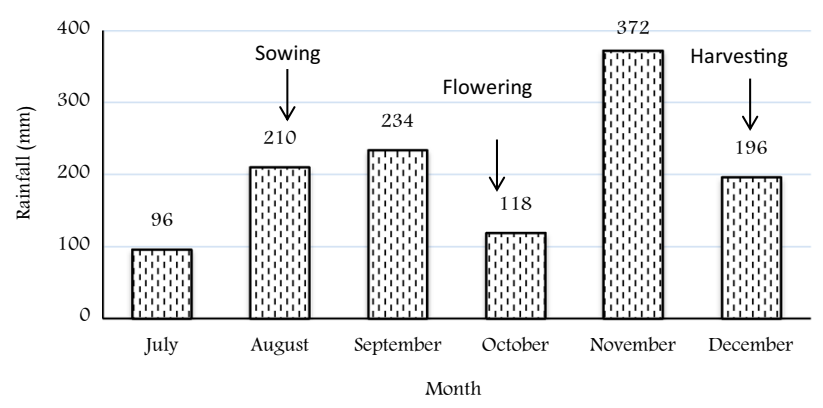

Fig. 2 Sowing and harvesting time and the monthly rainfall at the research site from July to December 2015. Total rainfall $=1225 \mathrm{~mm}$

light intensity was 0.197 and $0.174 \mathrm{~kW} / \mathrm{m}^{2}$ for the first and second trials, respectively.

\section{Soil collection and analysis}

Samples from the experimental site were collected at 0-20 cm depth using soil auger. The collected samples were bulked, air-dried, and sieved. The bulked soil was used to analyze the physical and chemical properties at applied agricultural resources (AAR) Laboratories Sdn Bhd. Malaysia. Micro Kjeldahl digestion techniques were used for the $\mathrm{N}$ content determination (Unkovich et al. 2008). $1 \mathrm{M} \mathrm{NH}_{4} \mathrm{OA}_{\mathrm{C}}$ buffered at $\mathrm{pH} 7$ was used for the cation exchange capacity determination. Atomic absorption spectrophotometry (AAS) was used to determine the cations ( $\mathrm{Ca}, \mathrm{Mg}, \mathrm{K}$, and $\mathrm{Na}$ ) contents in the $\mathrm{NH}_{4} \mathrm{OA}_{\mathrm{C}}$ solution. $1 \mathrm{M} \mathrm{KCl}$ was used to extract the exchangeable $\mathrm{Al}$ and the $\mathrm{Al}$ content in the extract was determined by AAS. The soil particle size was measured using the pipette method. The results of soil analysis are presented in Table 1. 
Table 1 Physico-chemical properties of the experiment site soil and the used biochar

\begin{tabular}{|c|c|c|c|}
\hline Properties & Soil & Properties & Biochar \\
\hline Chemical & & Chemical & \\
\hline $\mathrm{pH}(\mathrm{H} 20)$ & 4.72 & $\mathrm{pH}(\mathrm{H} 20)$ & 6.73 \\
\hline $\mathrm{P}(\mathrm{ppm})$ & 11.5 & Total $\mathrm{P}_{2} \mathrm{O}_{5}(\%)$ & 0.14 \\
\hline Carbon (\%) & 0.72 & Carbon (\%) & 18.40 \\
\hline Total N (\%) & 0.08 & Total N (\%) & 0.27 \\
\hline- & - & $\mathrm{S}(\%)$ & 0.07 \\
\hline \multicolumn{4}{|c|}{ Exchangeable cations (meq\%) } \\
\hline $\mathrm{K}$ & 0.04 & $\mathrm{~K}_{2} \mathrm{O}(\%)$ & 0.48 \\
\hline $\mathrm{Ca}$ & 0.58 & $\mathrm{CaO}(\%)$ & 0.18 \\
\hline $\mathrm{Mg}$ & 0.11 & $\mathrm{MgO}(\%)$ & 0.13 \\
\hline $\mathrm{Na}$ & 0.01 & $\mathrm{Na}(\%)$ & 0.01 \\
\hline $\mathrm{Al}$ & 0.67 & $\mathrm{Al}(\mathrm{ppm})$ & 82.0 \\
\hline- & - & $\mathrm{Fe}(\%)$ & 0.03 \\
\hline CEC & 4.0 & Conductivity $(\mu \mathrm{s} / \mathrm{cm})$ & 1728.5 \\
\hline- & - & $\mathrm{C} / \mathrm{N}$ ratio & 68.4 \\
\hline- & - & Total ash (\%) & 62.3 \\
\hline Physical & & - & - \\
\hline Sand $(\%)$ & 73 & - & - \\
\hline Silt (\%) & 5 & - & - \\
\hline Clay (\%) & 22 & - & - \\
\hline Texture & Sandy clay loam & - & - \\
\hline
\end{tabular}

\section{Description and source of the experimental materials}

The experimental materials used consisted of two landraces (Kaaro and Ex-Sokoto) of Bambara groundnut characterized by Musa et al. (2016), Christmas Island Rock Phosphate (CIRP) [32\% $\mathrm{P}_{2} \mathrm{O}_{5}, 3.6 \%$ solubility using $2 \%$ Neutral Ammonium Citrate (NAC)] which was obtained from the distribution company at Shah Alam, Malaysia and rice husk biochar was sourced from Ladybird Organic Farm, 43500 Jalan Broga, Semenyih, Selangor, Malaysia. The biochar was produced from intermediate pyrolysis of rice husk at $600{ }^{\circ} \mathrm{C}$ in a fixed bed pyrolysis system. The chemical properties of the biochar used are presented in Table 1.

\section{Treatments and experimental design}

Two levels of rice husk biochar ( 0 and $10 \mathrm{t} / \mathrm{ha}$ ) and four levels of phosphate $\left(0,20,40\right.$, and $60 \mathrm{~kg} \mathrm{P}_{2} \mathrm{O}_{5} /$ ha), equivalent to $0,555.6,1111.1$, and $1666.7 \mathrm{~kg} / \mathrm{ha}$ of Christmas Island Rock Phosphate (CIRP) were factorially combined to make a total of eight treatment combinations which were laid out in a randomized complete block design (RCBD) with three replicates. Gross plot measuring $3 \mathrm{~m} \times 3 \mathrm{~m}\left(9 \mathrm{~m}^{2}\right)$ and net plot area of $2.6 \mathrm{~m} \times 1.5 \mathrm{~m}\left(3.9 \mathrm{~m}^{2}\right)$ were maintained.

\section{Cultural practices}

The experimental area was ploughed, harrowed, and leveled prior to the onset of each trial using a tractor, after that plots were constructed. For the biochar treatments, uniform rice biochar was applied at the rate of $10 \mathrm{t} / \mathrm{ha}$ and thoroughly incorporated into the top $20 \mathrm{~cm}$ soil depth at sowing. After that, rock phosphate was uniformly applied as per treatment and incorporated into the same $20 \mathrm{~cm}$ depth to enhance its dissolution. The seeds were soaked overnight, pre-dried, and treated with the combination of fungicide and insecticide at planting. $1 \mathrm{~m}$ wide rows were constructed and the crop was planted on twin rows at a row spacing of $50 \mathrm{~cm}$. For both the varieties, a within the row spacing of $20 \mathrm{~cm}$ was maintained. Two seeds/hole were sown at 3-5 cm deep. Weeds were controlled manually using hoe and hand pulling. $20 \mathrm{~kg} \mathrm{~N} / \mathrm{ha}$ and $60 \mathrm{~kg} \mathrm{~K} \mathrm{~K}_{2} \mathrm{O} / \mathrm{ha}$ were applied using Urea $(46 \% \mathrm{~N})$ and Muriate of potash $\left(60 \% \mathrm{~K}_{2} \mathrm{O}\right)$ as a source of nutrients. The applied fertilizers were mixed thoroughly with the soil before planting. The plants were harvested at maturity using hand hoe for both experiments. This was followed by threshing, shelling, and air-drying of the harvested plants under shade to a constant weight. Samples were collected from the grain and stover for additional oven drying at temperatures of $70{ }^{\circ} \mathrm{C}$ for $72 \mathrm{~h}$ duration.

\section{Data collection}

Data were taken on $\mathrm{N}$ concentration, $\mathrm{N}$ content, \% nitrogen derived from the atmosphere (\% ndfa), $\mathrm{N}$ fixed in the shoot, and $\mathrm{N}$ fixed in the whole plant.

The plant nitrogen content was determined as the product of plant dry weight and $\% \mathrm{~N}$ in the plant as suggested by Unkovich et al. (2008):

Plant $\mathrm{N}$ content $(\mathrm{kg} / \mathrm{ha})=$ Plant dry weight $(\mathrm{kg} / \mathrm{ha})$ $\times \% \mathrm{~N}$ concentration of the plant.

${ }_{\text {The }}^{15} \mathrm{~N}$ analysis was conducted using the procedure reported by Musa et al. (2016).

$\mathrm{N}$ fixation was measured using ${ }^{15} \mathrm{~N}$ natural abundance (NA) procedure as suggested by Mohale et al. (2014). The ${ }^{15} \mathrm{~N} \mathrm{NA}$ of the whole plant (grain plus stover) was measured using the method of Unkovich et al. (2008)

$\delta^{15} \mathrm{~N}_{\text {whole plant }}=\frac{\sum\left(\delta^{15} \mathrm{~N}_{\text {grain }} \times \mathrm{N}_{\text {grain }}+\delta^{15} \mathrm{~N}_{\text {stover }} \times \mathrm{N}_{\text {stover }}\right)}{\sum\left(\mathrm{N}_{\text {grain }}+\mathrm{N}_{\text {stover }}\right)}$.

The \% ndfa was calculated using the method reported by Musa et al. (2016).

The $\mathrm{N}$ fixed in the shoot (grain + stover) and the total $\mathrm{N}$ fixed were as described by Mohale et al. (2014)

$\mathrm{N}$ fixed in the shoot $=$ Plant $\mathrm{N}$ content $($ shoot $) \times \%$ ndfa(shoot $)$

Total $\mathrm{N}$ fixed $=\mathrm{N}$ fixed in the shoot $($ grain + stover $) \times 1.4$. 


\section{Data analysis}

The data collected in the first and second trials were subjected to analysis of variance procedure using GenStat ${ }^{\circledR} 16$ th edition. However, for the mean analysis, the individual trials were treated as split plots and mean separation was carried out at 5\% level using Duncan's multiple range test (DMRT).

\section{Results and discussion}

\section{Grain and stover $\mathbf{N}$ concentration}

The grain and stover $\mathrm{N}$ concentration of Bambara groundnut as influenced by rice husk biochar and rock phosphate levels is presented in Table 2 .

\section{Effect of biochar}

The application of biochar in the first trial increased the grain $\mathrm{N}$ concentration of the crop from $3.31 \%$ recorded, where no biochar was applied to $3.53 \%$. However, there was no significant influence of biochar on the grain $\mathrm{N}$ concentration in the second trial (3.19-3.20\%) and the mean (3.25-3.36\%) (Table 2). Application of biochar decreased the stover $\mathrm{N}$ concentration in the first trial from $2.71 \%$ recorded in the no biochar treatments to $2.57 \%$. However, in the second trial (2.92-3.00\%) and the mean (2.78-2.82\%), the stover N concentration of the crop was not significantly influenced by the application of biochar (Table 2). The increase in grain and stover $\mathrm{N}$ concentration of the crop observed in the first trial due to biochar application is an evidence of the role of biochar in soil $\mathrm{N}$ retention and thus, making it more readily available for crop uptake (Liu et al. 2013).

\section{Effect of rock phosphate}

Rock phosphate application significantly influenced the $\mathrm{N}$ concentration of the grain in the second trial. The application of $20 \mathrm{~kg} \mathrm{P}_{2} \mathrm{O}_{5} /$ ha on the crop increased the grain $\mathrm{N}$ concentration from $3.11 \%$ recorded, where no rock phosphate was applied to $3.36 \%$. Furthermore, the increase in the rock phosphate application to $40 \mathrm{~kg} \mathrm{P}_{2} \mathrm{O}_{5} /$ ha decreased the grain $\mathrm{N}$ concentration to $3.10 \%$ and was significantly not different from 3.11 and $3.21 \%$ recorded in the treatments, where no rock phosphate was applied and where $60 \mathrm{~kg} \mathrm{P}_{2} \mathrm{O}_{5} /$ ha was applied, respectively. Similarly, the grain $\mathrm{N}$ concentration in the treatments that received the application of 20 and $60 \mathrm{~kg}$ $\mathrm{P}_{2} \mathrm{O}_{5} /$ ha was not significantly $(P>0.05)$ different. Hence, the $20 \mathrm{~kg} \mathrm{P}_{2} \mathrm{O}_{5}$ /ha application was optimum. However, the $\mathrm{N}$ concentration of the grain in the first trial (3.35-3.56\%) and the mean (3.23-3.38\%) was not significantly influenced by the rock phosphate application (Table 2). The stover $\mathrm{N}$ concentration of the crop recorded in the first trial (2.60-2.68\%), second trial (2.91-3.03\%), and the mean (2.77-2.85\%) was not significantly influenced by rock phosphate application (Table 2). The increase in $\mathrm{N}$ concentration of the crop observed in the treatments that received rock phosphate application of $20 \mathrm{~kg} \mathrm{P}_{2} \mathrm{O}_{5} /$ ha compared to the control (0 kg $\mathrm{P}_{2} \mathrm{O}_{5} / \mathrm{ha}$ ) indicates the importance of $\mathrm{P}$ in the nutrition of the crop. However, the inconsistent increase in the $\mathrm{N}$ concentration of the crop with additional application of rock phosphate indicates that $20 \mathrm{~kg} \mathrm{P}_{2} \mathrm{O}_{5} /$ ha was optimum. Sokoto and
Table 2 Grain and stover N concentration of Bambara groundnut as influenced by rice husk biochar and rock phosphate application

\begin{tabular}{|c|c|c|c|c|c|c|}
\hline \multirow[t]{3}{*}{ Treatments } & \multicolumn{6}{|c|}{ N Concentration $(\%)$} \\
\hline & \multicolumn{2}{|c|}{ First trial } & \multicolumn{2}{|c|}{ Second trial } & \multicolumn{2}{|l|}{ Mean } \\
\hline & Grain & Stover & Grain & Stover & Grain & Stover \\
\hline \multicolumn{7}{|c|}{ Biochar (B) (t/ha) } \\
\hline 0 & $3.31 \mathrm{~b}$ & $2.71 \mathrm{a}$ & 3.20 & 2.92 & 3.25 & 2.82 \\
\hline 10 & $3.53 \mathrm{a}$ & $2.57 \mathrm{~b}$ & 3.19 & 3.00 & 3.36 & 2.78 \\
\hline SEM & 0.064 & 0.042 & 0.039 & 0.045 & 0.037 & 0.031 \\
\hline$P$ value & 0.021 & 0.023 & 0.836 & 0.264 & 0.054 & 0.401 \\
\hline \multicolumn{7}{|c|}{ Rock phosphate (RP) $\left(\mathrm{kg} \mathrm{P}_{2} \mathrm{O}_{5} / \mathrm{ha}\right)$} \\
\hline 0 & 3.40 & 2.60 & $3.11 \mathrm{~b}$ & 2.98 & 3.25 & 2.79 \\
\hline 20 & 3.37 & 2.63 & $3.36 \mathrm{a}$ & 2.91 & 3.36 & 2.77 \\
\hline 40 & 3.35 & 2.66 & $3.10 \mathrm{~b}$ & 3.03 & 3.23 & 2.85 \\
\hline 60 & 3.56 & 2.68 & $3.21 \mathrm{ab}$ & 2.92 & 3.38 & 2.80 \\
\hline SEM & 0.090 & 0.061 & 0.055 & 0.063 & 0.053 & 0.044 \\
\hline$P$ values & 0.377 & 0.799 & 0.008 & 0.474 & 0.092 & 0.598 \\
\hline
\end{tabular}

Means followed by the same letter(s) within a column are not significantly different at $5 \%$ level using Duncan's multiple range test

$S E M$ standard error of mean, $P$ values probability values 
Singh (2008) reported rock phosphate application at $25 \mathrm{~kg}$ $\mathrm{P}_{2} \mathrm{O}_{5} /$ ha to increase the yield and its components in cowpea.

\section{Grain and stover $\mathbf{N}$ content}

The grain and stover $\mathrm{N}$ content of Bambara groundnut as influenced by rice husk biochar and rock phosphate levels is presented in Table 3 .

\section{Effect of biochar}

The grain $\mathrm{N}$ content in the first $(9.4-12.2 \mathrm{~kg} / \mathrm{ha})$ and second $(52.8-60.7 \mathrm{~kg} / \mathrm{ha})$ trial was not significantly influenced by biochar. However, in the mean, biochar application significantly increased the grain $\mathrm{N}$ content of the crop from $31.1 \mathrm{~kg} \mathrm{ha}^{-1}$ recorded, where no biochar was applied to $36.5 \mathrm{~kg} / \mathrm{ha}$ (Table 3). Similarly, biochar application increased the stover $\mathrm{N}$ content of the crop from $80.0,97.8$ and $88.9 \mathrm{~kg} /$ ha recorded, where no biochar was applied in the first trial, second trial, and the mean, respectively, to 93.9, 128.4, and $111.2 \mathrm{~kg} / \mathrm{ha}$, respectively (Table 3 ). The increase in the grain and stover $\mathrm{N}$ content of the crop observed in the treatments which received biochar application in the mean could be due to the role of biochar in enhancing $\mathrm{N}$ retention and utilization efficiency, thereby increasing the overall productivity of crops (Jin et al., 2016).

\section{Effect of rock phosphate}

The grain $\mathrm{N}$ content of the crop in the rock phosphate treatments recorded in the first trial $(9.3-12.7 \mathrm{~kg} / \mathrm{ha})$, second trial (52.4-63.8 kg/ha), and the mean (30.8-37.6 kg/ha) was not significantly influenced by rock phosphate (Table 3 ). Similarly, the stover $\mathrm{N}$ content of the crop in the first trial (85.4-90.0 kg/ha), second trial (106.3-117.5 kg/ha), and the mean $(96.3-103.3 \mathrm{~kg} / \mathrm{ha})$ was not influenced by rock phosphate (Table 3).

\section{Interactions}

Significant $(P<0.05)$ interaction between the biochar and the rock phosphate levels on the grain $\mathrm{N}$ content was observed in the second trial (Fig. 3) and the mean (Fig. 4). In the treatments, where biochar was not applied, the application of rock phosphate did not significantly influence the grain $\mathrm{N}$ content in the second trial and the mean. However, for the treatments, where biochar was applied, the application

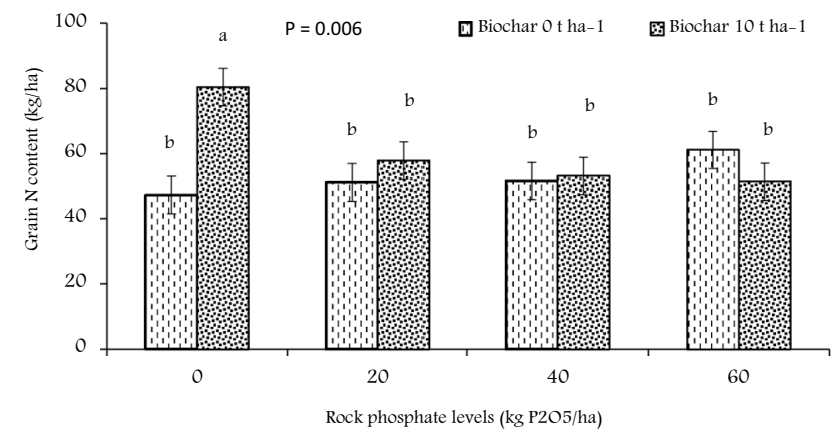

Fig. 3 Grain $\mathrm{N}$ content of Bambara groundnut in the second trial as influenced by biochar and rock phosphate levels interaction. Bars with the same letter(s) are not significantly different at 5\% level using Duncan's Multiple Range Test. Error bars represent standard error of mean (SEM) values
Table 3 Grain and stover $\mathrm{N}$ content of Bambara groundnut as influenced by rice husk biochar and rock phosphate application

\begin{tabular}{|c|c|c|c|c|c|c|}
\hline \multirow[t]{3}{*}{ Treatments } & \multicolumn{6}{|c|}{ N Content (kg/ha) } \\
\hline & \multicolumn{2}{|c|}{ First trial } & \multicolumn{2}{|c|}{ Second trial } & \multicolumn{2}{|l|}{ Mean } \\
\hline & Grain & Stover & Grain & Stover & Grain & Stover \\
\hline \multicolumn{7}{|c|}{ Biochar (B) (t/ha) } \\
\hline 0 & 9.4 & $80.0 \mathrm{~b}$ & 52.8 & $97.8 b$ & $31.1 \mathrm{~b}$ & $88.9 b$ \\
\hline 10 & 12.2 & $93.9 \mathrm{a}$ & 60.7 & $128.4 \mathrm{a}$ & $36.5 \mathrm{a}$ & $111.2 \mathrm{a}$ \\
\hline SEM & 1.11 & 4.26 & 2.88 & 7.20 & 1.54 & 4.18 \\
\hline$P$ value & 0.077 & 0.028 & 0.063 & 0.005 & 0.017 & 0.001 \\
\hline \multicolumn{7}{|c|}{ Rock phosphate (RP) $\left(\mathrm{kg} \mathrm{P}_{2} \mathrm{O}_{5} / \mathrm{ha}\right)$} \\
\hline 0 & 11.3 & 86.4 & 63.8 & 106.3 & 37.6 & 96.3 \\
\hline 20 & 9.9 & 86.0 & 54.5 & 112.2 & 32.2 & 99.1 \\
\hline 40 & 9.3 & 85.4 & 52.4 & 117.5 & 30.8 & 101.4 \\
\hline 60 & 12.7 & 90.0 & 56.3 & 116.6 & 34.5 & 103.3 \\
\hline SEM & 1.573 & 6.03 & 4.07 & 10.18 & 2.18 & 5.92 \\
\hline$P$ values & 0.433 & 0.947 & 0.234 & 0.859 & 0.152 & 0.855 \\
\hline
\end{tabular}

Means followed by the same letter(s) within a column are not significantly different at $5 \%$ level using Duncan's multiple range test

$S E M$ standard error of mean, $P$ values probability values 
of rock phosphate significantly decreased the grain $\mathrm{N}$ content from 80.4 and $47.2 \mathrm{~kg} / \mathrm{ha}$ recorded in the sole biochar treatments in the second trial and the mean, respectively, to $51.4-57.9 \mathrm{~kg} / \mathrm{ha}$ and $32.6-33.2 \mathrm{~kg} / \mathrm{ha}$, respectively. The difference among the treatments that received a combination of biochar and rock phosphate application and those which received rock phosphate alone without biochar or those treatments without either biochar or rock phosphate application was not observed. Overall, in the second trial and the mean, the sole biochar treatment was significantly higher than the other treatments.

The higher grain $\mathrm{N}$ content observed in the treatments which received sole application of biochar compared to other treatments could be explained by the ability of biochar to mobilize and retain soil nutrients including $\mathrm{N}$ and $\mathrm{P}$ for use by crops, thereby reducing the high demand for external $\mathrm{P}$

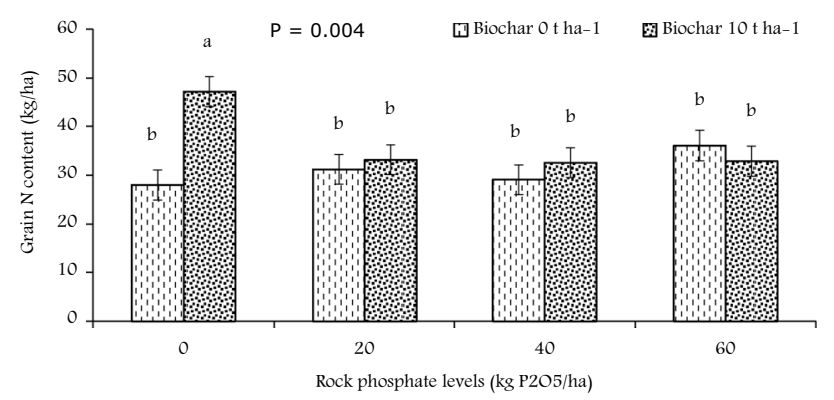

Fig. 4 Grain $\mathrm{N}$ content of Bambara groundnut in the combined as influenced by biochar and rock phosphate levels interaction. Bars with the same letter(s) are not significantly different at 5\% level using Duncan's Multiple Range Test. Error bars represent standard error of mean (SEM) values by the crop, whereas rock phosphate upon dissolution adds phosphorus to the soil which in this case appears to have a toxic effect on the crop. Van Zwieten et al. (2010) reported increased $\mathrm{N}$ retention due to biochar application. Biochar is also known to raise soil $\mathrm{pH}$ which makes the soil $\mathrm{P}$ more readily available for crop's uptake, which can make additional $\mathrm{P}$ from rock phosphate to have little or no impact on the crop. Yamato et al. (2006) found the biochar application to decrease the exchangeable $\mathrm{Al}^{3+}$ content of the soil by increasing the $\mathrm{pH}$ of the soil. It also increased the available $\mathrm{P}$ contents, exchangeable cations, and the total plant $\mathrm{N}$ content (Yamato et al. 2006).

\section{Total $\mathrm{N}$ content and percentage nitrogen derived from the atmosphere (\% ndfa)}

The influence of biochar and rock phosphate on the total $\mathrm{N}$ content and \% ndfa of Bambara groundnut is presented in Table 4.

\section{Effect of biochar}

Biochar application significantly increased the total $\mathrm{N}$ content of the crop from $89.3,150.7$, and $120.0 \mathrm{~kg} / \mathrm{ha}$ recorded, where no biochar was applied in the first trial, second trial, and the mean, respectively, to $106.1,189.1$, and $147.6 \mathrm{~kg} /$ ha, respectively (Table 4). However, no significant $(P>0.05)$ influence of biochar on the $\%$ ndfa of the crop was observed in the first trial (44.4-45.6\%), second trial (56.6-61.2\%), and the mean (51.1-52.8\%). The higher total $\mathrm{N}$ content observed in the treatments that received biochar application could be explained by the higher plant dry weight, since the $\%$ ndfa
Table 4 Total $\mathrm{N}$ content and percentage nitrogen derived from the atmosphere (\% ndfa) of Bambara groundnut as influenced by rice husk biochar and rock phosphate application

\begin{tabular}{|c|c|c|c|c|c|c|}
\hline \multirow[t]{2}{*}{ Treatments } & \multicolumn{2}{|l|}{ First trial } & \multicolumn{2}{|l|}{ Second trial } & \multicolumn{2}{|l|}{ Mean } \\
\hline & $\begin{array}{l}\text { Total N con- } \\
\text { tent }(\mathrm{kg} / \mathrm{ha})\end{array}$ & $\%$ ndfa $(\%)$ & $\begin{array}{l}\text { Total } \mathrm{N} \text { con- } \\
\text { tent }(\mathrm{kg} / \mathrm{ha})\end{array}$ & $\%$ ndfa $(\%)$ & $\begin{array}{l}\text { Total N con- } \\
\text { tent }(\mathrm{kg} / \mathrm{ha})\end{array}$ & $\%$ ndfa $(\%)$ \\
\hline \multicolumn{7}{|c|}{ Biochar (B) (t/ha) } \\
\hline 0 & $89.3 b$ & 45.6 & $150.7 \mathrm{~b}$ & 56.6 & $120.0 \mathrm{~b}$ & 51.1 \\
\hline 10 & $106.1 \mathrm{a}$ & 44.4 & $189.1 \mathrm{a}$ & 61.2 & $147.6 \mathrm{a}$ & 52.8 \\
\hline SEM & 4.88 & 1.78 & 9.45 & 2.53 & 5.32 & 1.55 \\
\hline$P$ value & 0.021 & 0.645 & 0.007 & 0.217 & 0.001 & 0.447 \\
\hline \multicolumn{7}{|c|}{ Rock phosphate (RP) $\left(\mathrm{kg} \mathrm{P}_{2} \mathrm{O}_{5} / \mathrm{ha}\right)$} \\
\hline 0 & 97.7 & 41.5 & 170.1 & 58.4 & 133.9 & 49.9 \\
\hline 20 & 95.8 & 47.7 & 166.8 & 57.0 & 131.3 & 52.4 \\
\hline 40 & 94.7 & 47.4 & 169.8 & 61.3 & 132.2 & 54.4 \\
\hline 60 & 102.7 & 43.4 & 172.9 & 58.9 & 137.8 & 51.2 \\
\hline SEM & 6.90 & 2.51 & 13.36 & 3.58 & 7.52 & 2.19 \\
\hline$P$ values & 0.849 & 0.238 & 0.991 & 0.865 & 0.932 & 0.529 \\
\hline
\end{tabular}

Means followed by the same letter(s) within a column are not significantly different at $5 \%$ level using Duncan's multiple range test

$S E M$ standard error of mean, $P$ values probability values 
of the crop was not influenced by the application of biochar. Yang et al. (2010) reported plant dry weight as the key driving factor behind total $\mathrm{N}$ content and $\mathrm{N}$ fixation in legumes. The \% ndfa (51.1-52.8\%) of the crop in the mean was within the range of 33-98\% reported by Mohale et al. (2014).

\section{Effect of rock phosphate}

No significant $(P>0.05)$ influence of rock phosphate on the total $\mathrm{N}$ content of the crop was observed in the first trial (94.7-102.7 kg/ha), second trial (166.8-172.9 kg/ha) and the mean (131.3-137.8 kg/ha). Similarly, the \% ndfa recorded by the crop in the rock phosphate treatments in the first trial (41.5-47.7\%), second trial (57.0-61.3\%), and the mean (49.9-54.4\%) was not significantly $(P>0.05)$ influenced by rock phosphate application (Table 4).

\section{Nitrogen fixed in the shoot and the total $\mathbf{N}$ fixed}

Nitrogen fixed in the shoot and the total $\mathrm{N}$ fixed of Bambara groundnut as influenced by biochar and rock phosphate levels are presented in Table 5.

\section{Effect of biochar}

Biochar application significantly $(P<0.05)$ increased the $\mathrm{N}$ fixed in the shoot of the crop from 89.0 and $64.9 \mathrm{~kg} / \mathrm{ha}$ recorded in the second trial and the mean, respectively, to 116.7 and $81.5 \mathrm{~kg} / \mathrm{ha}$, respectively. However, in the first trial, the $\mathrm{N}$ fixed in the shoot $(40.9-46.3 \mathrm{~kg} / \mathrm{ha}$ ) of the crop was not significantly influenced by the application of biochar. For the total $\mathrm{N}$ fixed, biochar application significantly
$(P<0.05)$ increased the total $\mathrm{N}$ fixed of the crop from 124.5 and $90.9 \mathrm{~kg} / \mathrm{ha}$ in the second trial and the mean, respectively, to 163.4 and $114.1 \mathrm{~kg} / \mathrm{ha}$, respectively. However, in the first trial, the total $\mathrm{N}$ fixed $(57.2-64.8 \mathrm{~kg} / \mathrm{ha}$ ) was not significantly $(P>0.05)$ influenced by biochar (Table 5$)$. The total $\mathrm{N}$ fixed (90.9-114.1 kg/ha) in the mean, where biochar was applied falls within the range of 4-200 kg/ha reported by Mohale et al. (2014). The higher $\mathrm{N}$ fixed in the shoot and the total $\mathrm{N}$ fixed observed in the second trial and the mean as a result of biochar application could be explained by the higher plant dry weight, since the \% ndfa of the crop was not influenced by the application of biochar. Yang et al. (2010) reported plant dry weight as the key driving factor behind $\mathrm{N}$ fixation in legumes. This shows that Bambara groundnut such as other crops could benefit from the use of biochar and hence, an option for increasing the yield of the crop in the study area.

\section{Effect of rock phosphate}

No significant $(P>0.05)$ influence of rock phosphate application on the $\mathrm{N}$ fixed in the shoot of the crop in the first trial (39.3-46.0 kg/ha), second trial (97.8-106.0 kg/ha), and the mean $(71.3-75.1 \mathrm{~kg} / \mathrm{ha})$ was observed. Similarly, the total $\mathrm{N}$ fixed in the first trial $(55.0-64.4 \mathrm{~kg} / \mathrm{ha})$, second trial (137.0-148.4 kg/ha), and the mean $(99.9-105.2 \mathrm{~kg} / \mathrm{ha})$ was not significantly $(P>0.05)$ influenced by the rock phosphate application (Table 5). The lack of significant $(P>0.05)$ response to rock phosphate application recorded in the $\mathrm{N}$ content and fixation of the crop despite the low soil P status, suggests that Bambara groundnut such as other legumes
Table 5 Nitrogen fixed in the shoot and total $\mathrm{N}$ fixed of Bambara groundnut as influenced by biochar and rock phosphate application

\begin{tabular}{|c|c|c|c|c|c|c|}
\hline \multirow[t]{3}{*}{ Treatments } & \multicolumn{6}{|c|}{$\mathrm{N}$ fixed (kg/ha) } \\
\hline & \multicolumn{2}{|c|}{ First trial } & \multicolumn{2}{|c|}{ Second trial } & \multicolumn{2}{|l|}{ Mean } \\
\hline & Shoot & Total & Shoot & Total & Shoot & Total \\
\hline \multicolumn{7}{|c|}{$\operatorname{Biochar}(\mathrm{B})(\mathrm{t} / \mathrm{ha})$} \\
\hline 0 & 40.9 & 57.2 & $89.0 \mathrm{~b}$ & $124.5 b$ & $64.9 \mathrm{~b}$ & $90.9 b$ \\
\hline 10 & 46.3 & 64.8 & $116.7 \mathrm{a}$ & $163.4 \mathrm{a}$ & $81.5 \mathrm{a}$ & $114.1 \mathrm{a}$ \\
\hline SEM & 2.53 & 3.55 & 7.96 & 11.15 & 4.18 & 5.85 \\
\hline$P$ value & 0.140 & 0.140 & 0.020 & 0.020 & 0.007 & 0.007 \\
\hline \multicolumn{7}{|c|}{ Rock phosphate (RP) $\left(\mathrm{kg} \mathrm{P}_{2} \mathrm{O}_{5} / \mathrm{ha}\right)$} \\
\hline 0 & 39.3 & 55.0 & 103.4 & 144.7 & 71.3 & 99.9 \\
\hline 20 & 46.0 & 64.4 & 97.8 & 137.0 & 71.9 & 100.7 \\
\hline 40 & 44.3 & 62.0 & 106.0 & 148.4 & 75.1 & 105.2 \\
\hline 60 & 44.7 & 62.5 & 104.1 & 145.8 & 74.4 & 104.2 \\
\hline SEM & 3.58 & 5.01 & 11.26 & 15.76 & 5.91 & 8.27 \\
\hline$P$ values & 0.574 & 0.574 & 0.961 & 0.961 & 0.961 & 0.961 \\
\hline
\end{tabular}

Means followed by the same letter(s) within a column are not significantly different at $5 \%$ level using Duncan's multiple range test

$S E M$ standard error of mean, $P$ values probability values 
could explore large soil volume for moisture, $\mathrm{P}$, and other nutrients.

\section{Conclusions}

The application of rice husk biochar increased the total mean of nitrogen content and $\mathrm{N}$ fixed by the crop from 120.0 and $90.9 \mathrm{~kg} / \mathrm{ha}$ to 147.6 and $114.1 \mathrm{~kg} / \mathrm{ha}$, respectively. However, the effect of rock phosphate application on the nitrogen content and fixation of the crop was not observed. Thus, biochar application at $10 \mathrm{t} / \mathrm{ha}$ alone was sufficient for nitrogen content and fixation of the crop. This implies that farmers in the study area can apply rice husk biochar at $10 \mathrm{t} / \mathrm{ha}$ to enhance the performance of the crop.

Acknowledgements The authors wish to acknowledge the support of the Crops for the Future and the University of Nottingham Malaysia Campus Doctoral Training Programme [Project Bam-001].

\section{Compliance with ethical standards}

Conflict of interest The authors wish to declare no conflict of interest.

Open Access This article is distributed under the terms of the Creative Commons Attribution 4.0 International License (http://creativeco mmons.org/licenses/by/4.0/), which permits unrestricted use, distribution, and reproduction in any medium, provided you give appropriate credit to the original author(s) and the source, provide a link to the Creative Commons license, and indicate if changes were made.

\section{References}

Arcand MM, Schneider KD (2006) Plant-and microbial-based mechanisms to improve the agronomic effectiveness of phosphate rock: a review. An Acad Bras Cienc 78(4):791-807. https://doi. org/10.1590/S0001-37652006000400013

Barrow CJ (2012) Biochar: potential for countering land degradation and for improving agriculture. Appl Geogr 34:21-28. https://doi. org/10.1016/j.apgeog.2011.09.008

Brough SH, Azam-Ali SN (1992) The effect of soil moisture on the proximate composition of Bambara groundnut (Vigna subterranea (L) Verdc). J Sci Food Agric 60(2):197-203. https://doi. org/10.1002/jsfa.2740600207

Chen X, Chen G, Chen L, Chen Y, Lehmann J, Mcbride MB, Hay AG (2011) Adsorption of copper and zinc by biochars produced from pyrolysis of hardwood and corn straw in aqueous solution. Bioresour Technol 102(19):8877-8884. https://doi.org/10.1016/j. biortech.2011.06.078

Collinson ST, Azam-Ali SN, Chavula KM, Hodson DA (1996) Growth, development and yield of Bambara groundnut (Vigna subterra$n e a)$ in response to soil moisture. J Agric Sci 126:307-318. https ://doi.org/10.1017/S0021859600074864

Dakora FD, Keya SO (1997) Contribution of legume nitrogen fixation to sustainable agriculture in Sub-Saharan Africa. Soil Biol Biochem 29(5):809-817. https://doi.org/10.1016/S0038 $-0717(96) 00225-8$
Dong X, Guan T, Li G, Lin Q, Zhao X (2016) Long-term effects of biochar amount on the content and composition of organic matter in soil aggregates under field conditions. J Soils Sediments 16(5):1481-1497. https://doi.org/10.1007/s11368-015-1338-5

Fardeau JC, Zapata F (2002) Phosphorus fertility recapitalization of nutrient-depleted tropical acid soils with reactive phosphate rock: an assessment using the isotopic exchange technique. Nutr Cycl Agroecosyst 63(1):69-79. https://doi.org/10.1023/A:1020583804 556

Graham PH, Vance CP (2000) Nitrogen fixation in perspective: an overview of research and extension needs. Field Crops Res 65(2):93-106. https://doi.org/10.1016/S0378-4290(99)00080-5

Hossain MK, Strezov V, Chan KY, Nelson PF (2010) Agronomic properties of wastewater sludge biochar and bioavailability of metals in the production of cherry tomato (Lycopersicon esculentum). Chemosphere 78(9):1167-1171. https://doi.org/10.1016/j.chemo sphere.2010.01.009

Howell JA, Eshbaugh WH, Guttman S, Rabakonandrianina E (1994) Common names given to Bambara groundnut (Vigna subterranea; Fabaceae) in Central Madagascar. Econ. Bot 48(2): 217-221. http://www.jstor.org/stable/4255620

Jin Z, Chen X, Chen C, Tao P, Han Z, Zhang X (2016) Biochar impact on nitrate leaching in upland red soil, China. Environ Earth Sci 75(14):1109. https://doi.org/10.1007/s12665-016-5906-9

Lehmann J, Da Silva Jr JP, Steiner C, Nehls T, Zech W, Glaser B (2003) Nutrient availability and leaching in an archaeological Anthrosol and a Ferralsol of the Central Amazon basin: fertilizer, manure and charcoal amendments. Plant Soil 249(2):343-357. https://doi. org/10.1023/A:1022833116184

Liu X, Zhang A, Ji C, Joseph S, Bian R, Li L, Pan G, Paz-Ferreiro J (2013) Biochar's effect on crop productivity and the dependence on experimental conditions - a meta-analysis of literature data. Plant Soil 373(1-2):583-594. https://doi.org/10.1007/s1110 4-013-1806-x

López-Bucio J, Hernández-Abreu E, Sánchez-Calderón L, NietoJacobo MF, Simpson J, Herrera-Estrella L (2002) Phosphate availability alters the architecture and causes changes in hormone sensitivity in the Arabidopsis root system. Plant Physiol 129(1):244-256. https://doi.org/10.1104/pp.010934

Major J, Rondon M, Molina D, Riha SJ, Lehmann J (2010) Maize yield and nutrition during 4 years after biochar application to a Colombian savanna oxisol. Plant Soil 333(1-2):117-128. https:// doi.org/10.1007/s11104-010-0327-0

Mohale KC, Belane AK, Dakora FD (2014) Symbiotic N nutrition, C assimilation, and plant water use efficiency in Bambara groundnut (Vigna subterranea L. Verdc) grown in farmers' fields in South Africa, measured using $15 \mathrm{~N}$ and $13 \mathrm{C}$ natural abundance. Biol Fertil Soils 50:307-319. https://doi.org/10.1007/s0037 4-013-0841-3

Musa M, Massawe F, Mayes S, Alshareef I, Singh A (2016) Nitrogen fixation and N-Balance studies on Bambara groundnut (Vigna subterranea L. Verdc.) Landraces grown on tropical acidic soils of Malaysia. Commun Soil Sci Plant Anal 47(4):533-542. https ://doi.org/10.1080/00103624.2016.1141928

Raboin LM, Razafimahafaly AHD, Rabenjarisoa MB, Rabary B, Dusserre J, Becquer T (2016) Improving the fertility of tropical acid soils: liming versus biochar application? A long term comparison in the highlands of Madagascar. Field Crops Res 199:99-108. https://doi.org/10.1016/j.fcr.2016.09.005

Radin R, Bakar RA, Ishak CF, Ahmad SH, Tsong LC (2018) Biocharcompost mixture as amendment for improvement of polybaggrowing media and oil palm seedlings at main nursery stage. Int $\mathrm{J}$ Recycl Org Waste Agric 7:11-23. https://doi.org/10.1007/s4009 3-017-0185-3

Rondon MA, Lehmann J, Ramírez J, Hurtado M (2007) Biological nitrogen fixation by common beans (Phaseolus vulgaris L.) 
increases with biochar additions. Biol Fertil Soils 43(6):699-708. https://doi.org/10.1007/s00374-006-0152-z

Sokoto AL, Singh A (2008) Yield and yield components of cowpea (Vigna unguiculata (L.) Walp.) as influenced by Sokoto phosphate rock and placement methods in the semi-arid zone of Nigeria. Nutr Cycl Agroecosyst 81:255-265. https://doi.org/10.1007/s1070 5-007-9161-z

Steiner C, Teixeira WG, Lehmann J, Nehls T, De Macedo JLV, Blum WE, Zech W (2007) Long term effects of manure, charcoal and mineral fertilization on crop production and fertility on a highly weathered Central Amazonian upland soil. Plant Soil 291(12):275-290. https://doi.org/10.1007/s11104-007-9193-9

Unkovich M, Herridge D, Peoples M, Cadisch G, Boddey B, Giller K, Alves B, Chalk P (2008) Measuring plant-associated nitrogen fixation in agricultural systems. ACIAR Monograph no. 136, pp 258. http://aciar.gov.au/publication/mn136
Van Zwieten L, Kimber S, Downie A, Morris S, Petty S, Rust J, Chan KY (2010) A glasshouse study on the interaction of low mineral ash biochar with nitrogen in sandy soil. Aust J Soil Res 48(7):569-576. https://doi.org/10.1071/SR10003

Yamato M, Okimori Y, Wibowo IF, Anshori S, Ogawa M (2006) Effects of the application of charred bark of Acacia mangium on the yield of maize, cowpea and peanut, and soil chemical properties in South Sumatra, Indonesia. Soil Sci Plant Nutr 52(4):489495. https://doi.org/10.1111/j.1747-0765.2006.00065.x

Yang JY, Drury CF, Yang XM, De Jong R, Huffman EC, Campbell CA, Kirkwood V (2010) Estimating biological $\mathrm{N}_{2}$ fixation in Canadian agricultural land using legume yields. Agric Ecosyst Environ 137:192-201. https://doi.org/10.1016/j.agee.2010.02.004

Publisher's Note Springer Nature remains neutral with regard to jurisdictional claims in published maps and institutional affiliations. 